Syntax Literate : Jurnal Ilmiah Indonesia p-ISSN: 2541-0849

e-ISSN : 2548-1398

Vol. 5, No. 5 Mei 2020

\title{
PENGARUH IMPLEMENTASI BIG DATA TERHADAP AUDITDI LEMBAGA PEMERINTAH (STUDI PADA KANTOR INSPEKTORAT KABUPATEN MAJALENGKA)
}

\author{
Eva Fauziah Ahmad dan Rizal Sukma Aliyudin \\ Universitas Majalengka (UNMA) \\ Email: evafahmad21@gmail.com dan rizalsukmaa@unma.ac.id
}

\section{Abstract}

Changes in storage patterns and types of data in the digital era have made several organizations look for ways to stay afloat amid competition. The explosion of data triggered the birth of the era of big data. Where in this case the data has an important role in strategic decision making. Therefore, those who are able to process and utilize data that are available in large volumes, varied diversity, high complexity and high speed of data addition, can benefit greatly. Meanwhile, in addition to big data business activities, it is also used in audit matters. Big Data in the context of the audit it becomes important to understand the difference between electronic data that will be used by auditors today using BDA with data that is traditionally used to obtain audit opinions. This study aims to determine the effect of big data on audits in government institutions and in this case the Inspectorate Office of Majalengka.

Keywords: Big Data, Internal Audit and Data analytic

\begin{abstract}
Abstrak
Perubahan pola penyimpanan dan jenis data di era digital membuat beberapa organisasi mencari cara agar tetap bertahan di tengah persaingan. Ledakan data tersebut memicu lahirnya era big data. Dimana dalam hal ini data memiliki peran penting dalam pengambilan keputusan strategis. Oleh karenanya, pihak yang mampu mengolah dan memanfaatkan data-data yang tersedia dalam volume besar, keragaman variatif, kompleksitas tinggi dan kecepatan penambahan data yang tinggi, dapat mengambil keuntungan yang besar. Sementara itu, selain untuk kegiatan bisnis big data juga digunakan dalam hal audit. Terkait dengan big data dalam konteks audit maka penting untuk memahami perbedaan antara data elektronik yang akan digunakan oleh auditor saat ini menggunakan BDA dengan data yang digunakan secara tradisional untuk mendapatkan opini audit. Penelitian ini bertujuan untuk mengetahui pengaruh big data terhadap audit di lembaga pemerintah, dalam hal ini adalah Kantor Inspektorat Kabupaten Majalengka.
\end{abstract}

Kata kunci: Big data, audit internal dan data analysis

\section{Pendahuluan}

Di era digital sekarang ini, kita hidup dengan data yang melimpah yang sangat berperan dalam membantu aktivitas sebagai alat bantu manusia yang memiliki 
kelebihan diantaranya kecepatan dalam mengolah data dibandingkan dengan sistem manual yang masih menggunakan pola pikir otak manusia (Akhyani, 2017).

Mulai dari profil media sosial, barang belanja favorit, rute yang kita ambil setiap hari untuk berangkat kerja dan sebagainya. Data-data tersebut berasal dari berbagai sumber, baik media sosial hingga aplikasi yang kita gunakan sehari-hari. Volume data yang sangat melimpah tersebut dimanfaatkan oleh organisasi untuk bertahan dari persaingan bahkan dari pemain non-tradisional.

Gelombang melimpahnya data tersebut mengarah kepada munculnya era big data. Dimana dalam hal ini data memiliki peran penting dalam pengambilan keputusan strategis. Oleh karenanya, pihak yang mampu mengolah dan memanfaatkan data-data yang tersedia dalam volume besar, keragaman variatif, kompleksitas tinggi dan kecepatan penambahan data yang tinggi, dapat mengambil keuntungan yang besar. Namun sayangnya, penerapan Big Data analytic (BDA) masih belum begitu populer di Indonesia. Sejauh ini tiga bidang usaha pengguna utama big data di Indonesia yaitu perusahaan telekomunikasi, perbankan, dan produsen barang-barang konsumsi ringan dan murah seperti minuman dan makanan kemasan (consumer goods) (Sirait, 2016) BDA menawarkan manfaat signifikan dalam hal peningkatan biaya dan efisiensi rantai pasokan, merespon lebih cepat terhadap lingkungan yang berubah, memberikan kekuatan yang lebih besar dalam hubungan dengan pemasok, dan meningkatkan penjualan serta operasi kemampuan perencanaan (Gunasekaran et al., 2017).

Penerapan teknologi big data pada suatu lembaga dapat dilihat dari fungsifungsi yang sudah tersedia pada IT infrastrukturnya, sehingga dapat menjalankan kerja yang berhubungan dengan aplikasi mobile, social, dan Big Data-Analytic. Diharapkan hasil kajian dapat memberikan informasi dan inspirasi sehingga implementasi teknologi Big Data di Indonesia dapat semakin luas, khususnya di lembaga pemerintahan.

Selain di bidang industri, big data juga memberikan banyak manfaat bagi lembaga pemerintah. Salah satu organisasi atau lembaga pemerintah yang sudah mengimplementasikan big data dalam mengelola pemerintahannya adalah Pemerintah Kota Bandung. Dengan dibangunnya Digital Command Center pada tahun 2015 telah membantu pihak pemerintah Kota Bandung dalam menyebarkan informasi.

Sementara itu, selain untuk kegiatan bisnis big data juga digunakan dalam hal audit. Big data dalam konteks audit maka menjadi penting untuk memahami perbedaan antara data elektronik yang akan digunakan oleh auditor saat ini menggunakan BDA dengan data yang digunakan secara tradisional untuk mendapatkan opini audit. Implementasi BDA akan memberikan kemampuan auditor internal dan eksternal dalam memeriksa seluruh data perusahaan untuk memastikan itu mematuhi GAAP, hukum yang berlaku, dan arahan manajemen yang lebih baru menggunakan berbagai teknik otomatis termasuk perangkat lunak audit umum dan audit kontinu yang dapat memeriksa semua transaksi perusahaan (Janvrin \& Watson, 2017). Ada beberapa faktor penghambat pemanfaatan big data dalam audit, diantaranya adalah terjadi pergerseran paradigma auditor, big data analysis dan sifat pengambilan keputusan audit, implikasi dari datafaction, pengelolaan keamanan data terkait dengan klien, dan data yang berantakan juga menjadi salah satu penghambat pemanfaatan big data dalam audit (Adrianto, 2018). 


\section{Metode Penelitian}

Penelitian ini merupakan jenis penelitian survey, yaitu penelitian yang dilakukan dengan menggunakan kuesioner sebagai alat penelitian. Atas pertimbangan tujuan penelitian, maka penelitian ini bersifat deskriptif verifikatif. Metode analisis deskriptif merupakan analisis yang dilakukan untuk menganalisis data dengan cara mendeskriptifkan atau menggambarkan data yang terkumpul sebagai mana adanya tanpa bermaksud membuat kesimpulan yang berlaku untuk umum atau generalisasi (Sugiyono, 2014). Populasi pada penelitian ini adalah seluruh auditor internal yang bekerja pada Kantor Inspektorat Kabupaten Majalengka.

\section{Hasil dan Pembahasan}

\section{A. Hasil}

Hasil penelitian mengenai Pengaruh Implementasi Big Data (X) terhadap Audit di Lembaga Pemerintah (Y) pada Kantor Inspektorat Kabupaten Majalengka diperoleh data dan informasi sebagai berikut. Berdasarkan hasil perhitungan dengan menggunakan SPSS 20, diperoleh hasil sebagai berikut:

\section{Tabel 1}

\section{Persamaan Regresi Linier Sederhana}

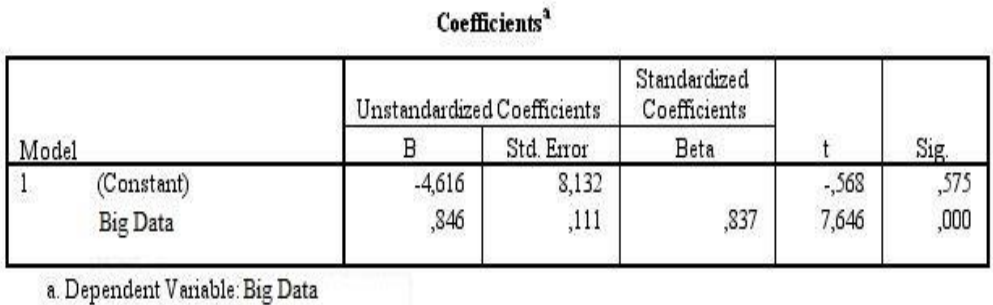

Tabel di atas merupakan persamaan regresi linier sederhana pengaruh implementasi big data terhadap keefektivitasan dalam pelaksanaan audit organisasi. Berdasarkan tabel di atas dapat dibentuk persamaan regresi linier sederhana sebagai berikut:

$$
Y=-4,616+0,846 x
$$

Dari persamaan di atas, diperoleh informasi bahwa nilai koefisien regresi untuk variabel implementasi big data adalah sebesar 0,846. Artinya ketika implementasi big data meningkat satu, maka audit di lembaga pemerintah akan meningkat sebesar 0,846 .

Tabel 2

Hasil Uji Normalitas Data

One-Sample Kolmogorov-Smirnov Test

\begin{tabular}{|c|c|c|c|}
\hline & & Big Data & Audit \\
\hline $\begin{array}{l}\text { N } \\
\text { Normal Parameters }{ }^{a, b} \\
\text { Most Extreme Differences } \\
\text { Kolmogorov-Smimov } \text { Z } \\
\text { Asymp. Sig. (2-tailed) }\end{array}$ & $\begin{array}{l}\text { Mean } \\
\text { Std. Deviation } \\
\text { Absolute } \\
\text { Positive } \\
\text { Negative }\end{array}$ & $\begin{array}{r}27 \\
72,7947 \\
10,26159 \\
, 107 \\
, 087 \\
-, 107 \\
, 558 \\
, 915\end{array}$ & $\begin{array}{r}27 \\
56,9693 \\
10,37308 \\
, 140 \\
, 140 \\
-, 119 \\
, 727 \\
, 666\end{array}$ \\
\hline
\end{tabular}


Tabel di atas menunjukan hasil pengujian normalitas data dengan menggunakan Kolmogorov Smoirnov. Berdasarkan data yang disajikan pada tabel di atas, terlihat bahwa nilai asymp. Sig yang diperoleh untuk kedua variabel masing-masing sebesar 0,915 dan 0,666. Kedua nilai ini berada di atas 0,05 sehingga dapat disimpulkan bahwa data yang digunakan berdistribusi normal, hal ini menunjukan bahwa tidak terdapat pelanggaran asumsi normalitas.

\section{Tabel 3}

Hasil Uji Heteroskedastisitas

Coefficients $^{2}$

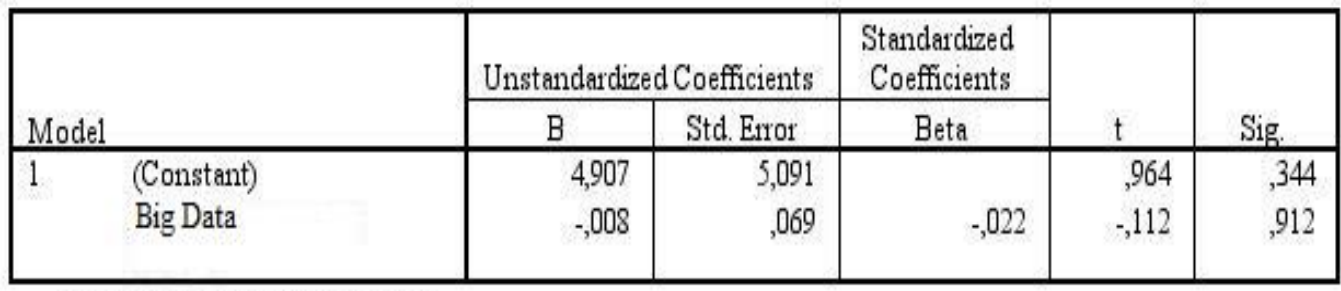

a. Dependent Variable: Absolut

Dari tabel output di atas, terlihat bahwa nilai signifikansi yang diperoleh informasi bahwa nilai signifikansi dari hasil regresi antara variabel bebas (Implementasi Big Data) terhadap nilai absolute sebesar 0,912. Nilai ini berada di atas 0,05 yang menunjukan bahwa koefisien regresi tidak signifikan, sehingga dapat disimpulkan bahwa varians residual bersifat homokedastisitas. Dari kedua pengujian heteroskedastisitas di atas diketahui bahwa tidak terdapat pelanggaran asumsi klasik sehingga analisis regresi linier sederhana dapat dilanjutkan

Tabel 4

Analisis Korelasi Pearson

Correlations

\begin{tabular}{|c|c|c|c|}
\hline & & Big Data & Audit \\
\hline Big Data & $\begin{array}{l}\text { Pearson Correlation } \\
\text { Sig. (2-tailed) } \\
\mathrm{N}\end{array}$ & $\begin{array}{r}1 \\
27\end{array}$ & $\begin{array}{r}, 837^{1} \\
, 000 \\
27\end{array}$ \\
\hline Audit & $\begin{array}{l}\text { Pearson Correlation } \\
\text { Sig. (2-tailed) } \\
\text { N }\end{array}$ & $\begin{array}{r}, 837^{11} \\
, 000 \\
27\end{array}$ & $\begin{array}{r}1 \\
27\end{array}$ \\
\hline
\end{tabular}

**. Correlation is signific ant at the 0.01 level (2-tailed).

Berdasarkan tabel output di atas, terlihat bahwa nilai koefisien korelasi yang diperoleh antara implementasi big data dengan audit di lembaga pemerintah adalah sebesar 0,837 . Nilai korelasi bertanda positif yang menunjukan bahwa hubungan yang terjadi antara keduanya adalah searah. Dimana semakin baik implementasi big data, maka akan diikuti pula oleh semakin baiknya kinerja organisasi pemerintah daerah. Dengan demikian dapat disimpulkan bahwa 
hubungan yang terjadi antara implementasi big data dengan audit di lembaga pemerintah adalah hubungan yang sangat kuat $(0,800-1,000)$.

Tabel 5

Koefisien Determinasi

Model Sumumary'

\begin{tabular}{|l|r|r|r|r|}
\hline Model & R & RSquare & $\begin{array}{c}\text { Adjusted R } \\
\text { Square }\end{array}$ & $\begin{array}{c}\text { Std. Error of } \\
\text { the Estimate }\end{array}$ \\
\hline 1 &, $837^{\mathrm{a}}$ &, 700 &, 688 & 5,78980 \\
\hline
\end{tabular}

a. Predictors: (Constant), Big Data

b. Dependent Variable:Audit

Berdasarkan tabel di atas, diperoleh informasi bahwa nilai koefisien korelasi atau (R) adalah sebesar 0,837. Dengan demikian koefisien determinasi dapat dihitung sebagai berikut:

$$
\begin{aligned}
& \mathrm{Kd}=(r)^{2} \times 100 \% \\
& \mathrm{Kd}=(0,837)^{2} \times 100 \% \\
& \mathrm{Kd}=70 \%
\end{aligned}
$$

Dari hasil perhitungan di atas terlihat bahwa nilai koefisien determinasi yang diperoleh sebesar 70\%. Dengan demikian dapat dikatakan bahwa implementasi big data memberikan pengaruh terhadap audit di lembaga pemerintah sebesar 70\%, sedangkan sisanya sebesar $100 \%-70 \%=30 \%$ merupakan pengaruh dari variabel lain yang tidak diteliti.

Tabel 6

Pengujian Hipotesis

Coefficients $^{2}$

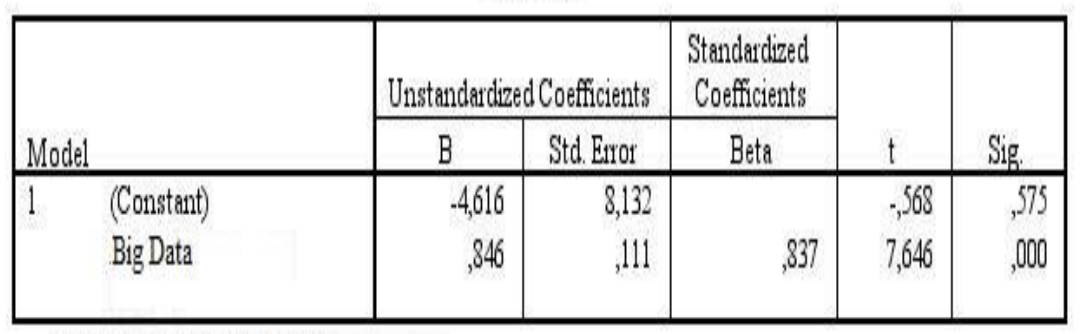

a. Dependent Variable: Audit

Berdasarkan tabel di atas, diperoleh informasi bahwa nilai t-hitung yang diperoleh variabel implementasi big data sebesar 7,646. Nilai ini akan dibandingkan dengan nilai t-tabel pada tabel distribusi t. Dengan alpha 0,05 dan $\mathrm{df}=\mathrm{n}-\mathrm{k}-1=27-1-1=25$, diperoleh nilai t-tabel untuk pengujian dua pihak \pm 2,060. Dari nilai-nilai di atas, terlihat bahwa nilai t-hitung yang diperoleh lebih besar dari nilai t-tabel. Sesuai dengan kriteria pengujian hipotesis bahwa $\mathrm{H}_{0}$ ditolak dan $\mathrm{H}_{1}$ diterima. Artinya implementasi big data berpengaruh signifikan terhadap keefektivitasan audit di lembaga pemerintah. 


\section{B. Pembahasan}

Berdasarkan hasil pengolahan data dan pegujian statistik yang sesuai serta dengan mempelajari buku-buku dan literature yang berkaitan, maka dapat dijelaskan bahwa implementasi big data berpegaruh positif terhadap keefektivitasan audit di lembaga pemerintah dalam hal ini Kantor Inspektorat Kabupaten Majalengka. Berdasarkan Tabel diatas, terlihat bahwa nilai persentase yang diperoleh variabel implementasi big data sebesar 80,98\%. Jika mengacu pada rentang pengakategorian skor jawaban, nilai sebesar $80,98 \%$ berada diantara rentang 68,01\%-84\% dengan kategori baik. Dengan demikian dapat disimpulkan bahwa implementasi big data pada Kantor Inspektorat Kabupaten Majalengka dinilai baik dengan penjabaran sebagai berikut:

1. Efisiensi

Data jawaban responden atas pernyataan koesioner pada tabel 4.6 menunjukan bahwa nilai persentase yang diperoleh dari keempat pernyataan yang membentuk efisiensi adalah $82,22 \%$. Nilai ini terletak antara 68\%-84\% dengan kategori tinggi. Hal ini ditunjukan juga dengan perolehan nilai persentase dari keempat pernyataan berada dalam kategori tinggi. Nilai tertinggi yang diperoleh dari keempat pernyataan diperoleh nilai sebesar 88,89\% yang berkenaan dengan penggunaan sistem big data sudah sesuai dengan perencanaan yang disusun. Selain itu dalam melakukan semua kegiatannya, Kantor Inspektorat Majalengka menggunakan sumber daya secara efisien dimana nilai persentase yang diperoleh sebesar 84,44\%. Dapat dikatakan efisien jika kantor inspektorat telah menghasilkan output (suatu hasil kerja) dengan memanfaatkan input yang berupa anggaran yang diberikan oleh pemerintah sesuai dengan yang sudah direncanakan.

2. Efektivitas

Tabel di atas menjelaskan tanggapan-tanggapan responden berkenaan dengan 10 pernyataan yang diajukan mengenai efektivitas anggaran. Dari sepuluh pernyataan yang diajukan, diperoleh nilai persentase sebesar 79,93\%. Nilai ini terletak antara 68\%-84\% dengan kategori tinggi. Hal ini menandakan bahwa efektivitas anggaran berbasis kinerja dilingkungan Kecamatan Majalengka termasuk dalam kategori baik. Tingginya efektivitas anggaran terjadi karena keseluruhan program yang telah dilaksanakan ternyata mampu meningkatkan partisipasi masyarakat, ditunjukan dengan perolehan nilai persentase tertinggi sebesar $85,19 \%$. Selain itu, penyelenggaraan fungsi organisasi atau unit kerja selalu dilakukan dengan baik dan pelaksanaan suatu kegiatan yang memerlukan anggaran yang besar penggunaannya selalu dapat dipertanggung jawabkan dengan baik, nilai persentase yang dicapai masingmasing sebesar $84,44 \%$. Dan seluruh program yang telah dilaksanakan dapat menghasilkan pelayanan publik yang lebih baik, nilai persentase yang diperoleh sebesar 83,19\%. 


\section{Ekonomis}

Tabel di atas menjelaskan tanggapan-tanggapan responden terhadap indikator ekonomis dalam implementasi big data. Dari data yang disajikan pada tabel di atas, terlihat bahwa nilai persentase yang diperoleh dari keenam pernyataan sebesar $79,75 \%$. Nilai ini terletak antara rentang interval $68 \%$ $84 \%$ dengan kategori tinggi. Salah satu faktor yang menjadi tingginya ekonomis dalam big data karena jika data yang didapatkan semakin banyak maka kita bisa memanfaatkan data untuk mengambil keputusan, cost reduction merupakan pengurangan biaya yang bisa diterapkan oleh perusahaan sebagai langkah menurunkan anggaran sesuai dengan kebijakan masing-masing organisasi.

\section{Kesimpulan}

Berdasarkan hasil penelitian dan pembahasan yang telah dilakukan, dapat disimpulkan bahwa implementasi big data berpegaruh positif terhadap keefektivitasan audit di lembaga pemerintah dalam hal ini Kantor Inspektorat Kabupaten Majalengka. 


\section{BIBLIOGRAFI}

Adrianto, Zaldy. (2018). Auditing in the era of big data: a literature review. Jurnal Akuntansi Dan Keuangan, 17(1).

Akhyani, Muhammad. (2017). Sistem Pengolahan Data Analisa Kredit Berbasis Web Pada PT. Bank Sinar Mas Cirebon. Syntax Literate; Jurnal Ilmiah Indonesia, 2(12), 88-111.

Gunasekaran, Angappa, Papadopoulos, Thanos, Dubey, Rameshwar, Wamba, Samuel Fosso, Childe, Stephen J., Hazen, Benjamin, \& Akter, Shahriar. (2017). Big data and predictive analytics for supply chain and organizational performance. Journal of Business Research, 70, 308-317.

Janvrin, Diane J., \& Watson, Marcia Weidenmier. (2017). "Big Data": A new twist to accounting. Journal of Accounting Education, 38, 3-8.

Sirait, Emyana Ruth Eritha. (2016). Implementasi Teknologi Big Data Di Lembaga Pemerintahan Indonesia. Jurnal Penelitian Pos Dan Informatika, 6(2), 113-136.

Sugiyono, P. D. (2014). Metode Penelitian Kuantitatif Kualitatif dan R\&D . Indonesia: ALFABETA. 